\title{
Guillermo Cabrera Infante and the Meanings of Literature
}

\section{Rodica Grigore ${ }^{1}$}

Unanimously considered one of the greatest Latin American writers of the entire $20^{\text {th }}$ century, the Cuban Guillermo Cabrera Infante is also the author who, despite his tendency to ignore the pattern of traditional fiction, also succeeds in establishing a new type of connection to the great tradition of world literature, following the steps of Miguel de Cervantes and, up to a certain point, symbolically going back to the celebrated model of Don Quixote. Cabrera Infante's masterpiece, Three Trapped Tigers (Tres tristes tigres, 1965) thus questions the place and meanings of literature itself in the contemporary world, and the characters involved in the process organize their (fictitious) life around textual aspects, underlining the importance of a new kind of interpretative relationship, to be established between reader and writer. [Article copies available for a fee from The Transformative Studies Institute. E-mail address: journal@transformativestudies.org Website: http://www.transformativestudies.org (02022 by The Transformative Studies Institute. All rights reserved.]

KEYWORDS: Modernity, Latin American Novel, Literary Strategy, Irony, Reader.

\footnotetext{
${ }^{\mathbf{1}}$ Rodica Grigore, Ph.D., is senior lecturer in Comparative Literature at "Lucian Blaga" University of Sibiu, Romania. She is the author of several critical studies, such as: Despre cărţi şi alţi demoni [Of Books and Other Demons, 2002], Retorica măştilor în proza interbelică românească [The Rhetoric of Masks in Romanian Modern Fiction, 2005], Lecturi in labirint [Readings in the Labyrinth, 2007], Măşti, caligrafie, literatură [Masks, Calligraphy, Literature, 2011], In oglinda literaturii [In the Mirror of Literature, 2011], Meridianele prozei [Fiction's Meridians, 2013], Realismul magic in proza latinoamericană a secolului XX. [Magical Realism in Latin-American Fiction of the $20^{\text {th }}$ Century, 2015], Tigrul și steaua. Violență şi exil în proza latino-americană a secolului $X X\left[\right.$ The Tiger and the Star. Violence and Exile in Latin-American Fiction of the $20^{\text {th }}$ Century, 2021]. She has also translated into Romanian the essays of Octavio Paz, Children of the Mire, (2003/2017) and the poems of the Colombian writer Manuel Cortés Castañeda, Oglinda celuilalt [The Mirrored Other, 2006]. Between 2005 and 2012 she has been coordinating the anthology of The International Theatre Festival of Sibiu. She is also known as a translator from English and Spanish. Address correspondence to: Dr. Rodica Grigore; e-mail: rodica.grigore@gmail.com.
} 